\title{
Laboratory Investigation of Geobag Revetment Performance in Rivers
}

\author{
Leila Khajenoori ${ }^{1}$, Grant Wright ${ }^{2, *} \mathbb{B}$ and Martin Crapper ${ }^{3}$ \\ 1 School of Engineering, University of Central Lancashire (UCLan), Preston PR1 2HE, UK; \\ lkhajenoori@uclan.ac.uk \\ 2 Institute for Infrastructure and Environment, Heriot Watt University, Edinburgh EH14 4AS, UK \\ 3 Mechanical and Construction Engineering, Faculty of Engineering and Environment, \\ Northumbria University, Newcastle-upon-Tyne NE1 8ST, UK; martin.crapper@northumbria.ac.uk \\ * Correspondence: g.b.wright@hw.ac.uk
}

Citation: Khajenoori, L.; Wright, G.; Crapper, M. Laboratory

Investigation of Geobag Revetment Performance in Rivers. Geosciences 2021, 11, 304. https://doi.org/ 10.3390 /geosciences 11080304

Academic Editors: Luca Pagano and Jesus Martinez-Frias

Received: 22 June 2021

Accepted: 19 July 2021

Published: 22 July 2021

Publisher's Note: MDPI stays neutral with regard to jurisdictional claims in published maps and institutional affiliations.

Copyright: (c) 2021 by the authors. Licensee MDPI, Basel, Switzerland. This article is an open access article distributed under the terms and conditions of the Creative Commons Attribution (CC BY) license (https:// creativecommons.org/licenses/by/ $4.0 /)$.
Abstract: Geobag (sand-filled geotextile bags) revetments have recently emerged as long-term riverbank protection measures in developing countries; however, their performance is still not well understood. The hydraulic stability of geobag revetments used for riverbank protection has been studied within an extensive laboratory programme to improve our understanding of the complete failure processes of geobag revetments. A 1:10 scale distorted physical model was tested in a laboratory flume, comparing a range of different construction methods and revetment side slopes, subjected to different flow loading. The results indicate that whilst failure mechanisms are highly dependent on water depth and revetment slope, the construction method had no noticeable impact. It was thus concluded that the dominating factor is the friction between individual geobags, which itself is dependent on bag longitudinal overlap rather than a specific construction method.

Keywords: erosion; failure; geobag; revetment; riverbank

\section{Introduction}

Riverbank erosion is a significant problem in many rivers, including those which flow through low-lying alluvial plains and more upstream locations. Morphologically, riverbank erosion can lead to changes in the characteristics of river channels and flood zones, which in turn can lead to the loss of fertile agricultural land, damage to properties and fluvial infrastructure, as well as danger to human and animal life. To counter such issues, geobag (sand-filled geotextile bags) revetments have recently emerged as long-term riverbank protection measures in developing countries, primarily due to their effectiveness, low cost, and ready availability; good examples of their successful implementation include the Yangtze River [1] and Changjiang River [2] in China, and the Jamuna and Meghna Rivers in Bangladesh [3].

Notwithstanding the applications noted above, the vast majority of related research has previously focused on geobag performance in coastal situations [4-9], which reflects their relatively widespread use in this environment. Field studies of coastal geobag structures have shown that failure mechanisms can be greatly influenced by wave action. Overtopping, sliding, puncturing, pull-out, and toe scour have been identified as the most common failure modes [10-12]; friction, inertia, drag, and lift forces are the main forces which govern these failures [8]. However, the perpendicular wave action found in coastal scenarios is not significant in fluvial applications, where the flow direction is generally parallel to the riverbank, so the performance and failure mechanisms of geobag revetments in rivers are considerably different from that of coastal structures.

One study that has looked at the use of geobags in the fluvial environment was conducted as part of the wider Jamuna-Meghna River erosion protection scheme in Bangladesh [13]. In terms of failure modes, NHC reported [13] that inadequate bag 
coverage and toe scour were the main reasons for failure due to sliding/slip and slumping. During a field study in 2009, the potential failure mechanisms of geobag revetments in the Jamuna River were identified as pull-out/dislodgement, sliding, slumping, and physical damage [14]. NHC [13] conducted a range of bag-drop and launch tests using a 1:20 scale in a laboratory. The launch tests highlighted that "standard" $126 \mathrm{~kg}$ bags are the optimum, feasible. bags for revetment stability under high flow velocities (up to $4.5 \mathrm{~m} / \mathrm{s}$ ); locally, $126 \mathrm{~kg}$ bags are considered the largest geobags safe to handle by two people [15]. According to previous experimental work [13], manually dropping $126 \mathrm{~kg}$ bags into place from the riverbank or dumping pontoons located on the river produces typical revetment side slopes of $1 \mathrm{~V}: 2 \mathrm{H}$. However, it seems reasonable to assume that the existing (pre-revetment) side slope of any riverbank will play a significant role in the final revetment side slope, and that the final revetment slope may influence the overall stability of a geobag revetment. In the field, different placement methods (e.g., riverbank launching, pontoon launching) can lead to a wide range of different construction bonds [15].

To date, the only laboratory work investigating geobag revetment performance in rivers has been undertaken by Akter et al [16], who attempted to investigate the behaviour of a geobag revetment numerically and experimentally under different hydrodynamic loads and toe scour conditions. It was found that failure mechanisms of geobag revetment could be initiated through a combination of uplifting, pull-out, and sliding.

In all previous studies, the performance of geobag revetments was investigated with an emphasis on incipient motion during construction/launching [2] and after revetment construction $[13,16]$, and they did not link the complete processes of failure to underlying hydraulic loading. Notwithstanding recent advances, additional research is still required to better understand the performance of geobag revetments in the fluvial environment.

The work presented in this paper aims to experimentally investigate the effect of key revetment characteristics (construction method and slope) on the performance of geobag revetments on a fixed (non-erodible) bed, which will also provide the necessary data to develop a discrete element model (DEM) capable of numerically simulating complete revetment failure processes.

\section{Geobag and Hydrodynamic Forces}

According to Recio and Oumeraci [8], failure mechanisms progressed with increasing flow velocity in and around the bag voids, which led to an increase in associated hydrodynamic forces (drag force, lift force), subtly altering the balance with the other forces (buoyancy, bag self-weight), as shown in Figure 1. In the case of geobag revetment in rivers, with associated acceleration, inertia force is assumed to be negligible.

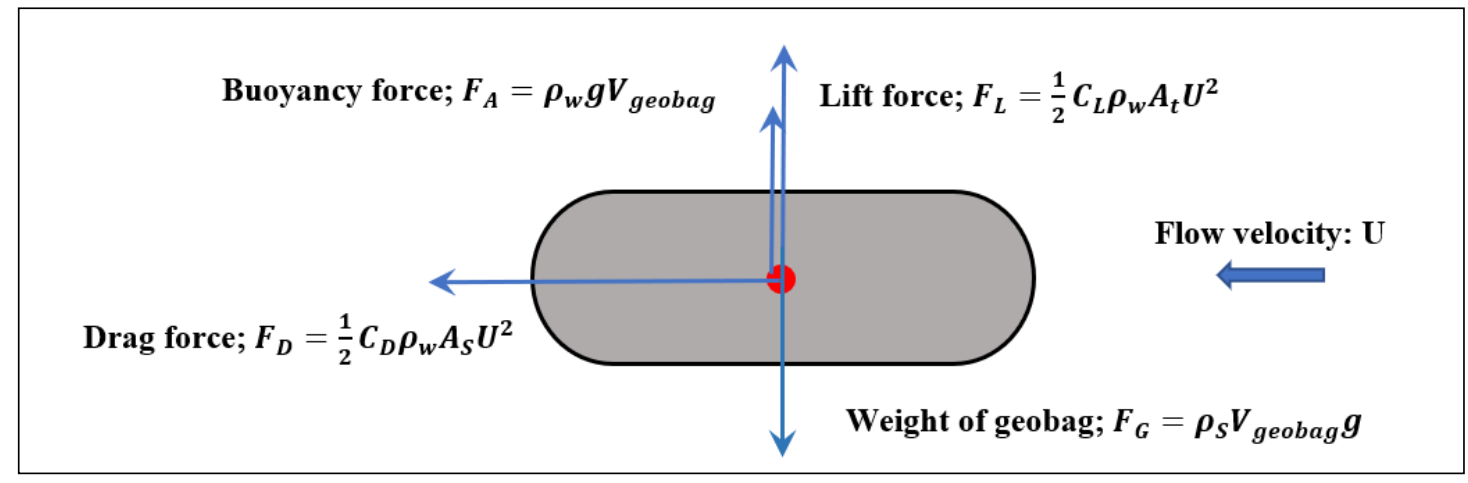

Figure 1. Forces acting on a submerged geobag.

\section{Mobilising and Resisting Forces on Submerged Geobags}

To understand the mechanisms which affect the hydraulic stability of a geobag revetment, the balance of forces that are acting on a geobag needs to be considered (Figure 1). 
The flow on and around a geobag with horizontal velocity $U$ in a steady flow condition results in three types of forces as explained by Equations (1)-(3) [7]:

Drag force:

$$
F_{D}=\frac{1}{2} C_{D} \rho_{w} A_{S} U^{2}
$$

where $C_{D}$ is a drag coefficient which depends on the shape and roughness of the geobags, $\rho_{w}$ is the density of water, $U$ is the horizontal flow velocity, and $A_{S}$ is the cross area normal to the flow.

Lift Force:

$$
F_{L}=\frac{1}{2} C_{L} \rho_{w} A_{t} U^{2}
$$

where $C_{L}$ is the lift coefficient, and $A_{t}$ is the projected area of the geobag in the flow direction.

Buoyancy Force:

$$
F_{A}=\rho_{w} g V_{g e o b a g}
$$

where $g$ is the gravitational acceleration and $V_{\text {geobag }}$ is the volume of geobag.

The resisting forces are essentially due to the weight of the geobag under buoyancy, thus:

Weight of geobag:

$$
F_{G}=\rho_{s} V_{\text {geobag } g}
$$

where $\rho_{s}$ is the density of the dry geobags

In addition to illustrating the physical theory behind each failure mode, these equations have also been incorporated into a DEM to numerically simulate the failure mechanisms in geobag revetment.

\section{Materials and Methods}

\subsection{Overview}

Experimental tests were performed in a hydraulic flume $(22 \mathrm{~m}$ long, $0.75 \mathrm{~m}$ wide, and $0.50 \mathrm{~m}$ deep). Since the construction of a geobag revetment along the whole length of the flume was not feasible, a $3 \mathrm{~m}$ long prototype geobag revetment was placed within the quasiuniform, steady-flow zone within the flume. Depending on the specific design criteria (slope and bond, see below), the prototype geobag revetment consisted of 600-800 geobags (Figure 2). The channel bed slope was set to $5.5 \times 10^{-3}(1 \mathrm{~V}: 4000 \mathrm{H})$, which replicates that in the Jamuna River, making the present work directly comparable to previous similar laboratory studies $[13,17]$.

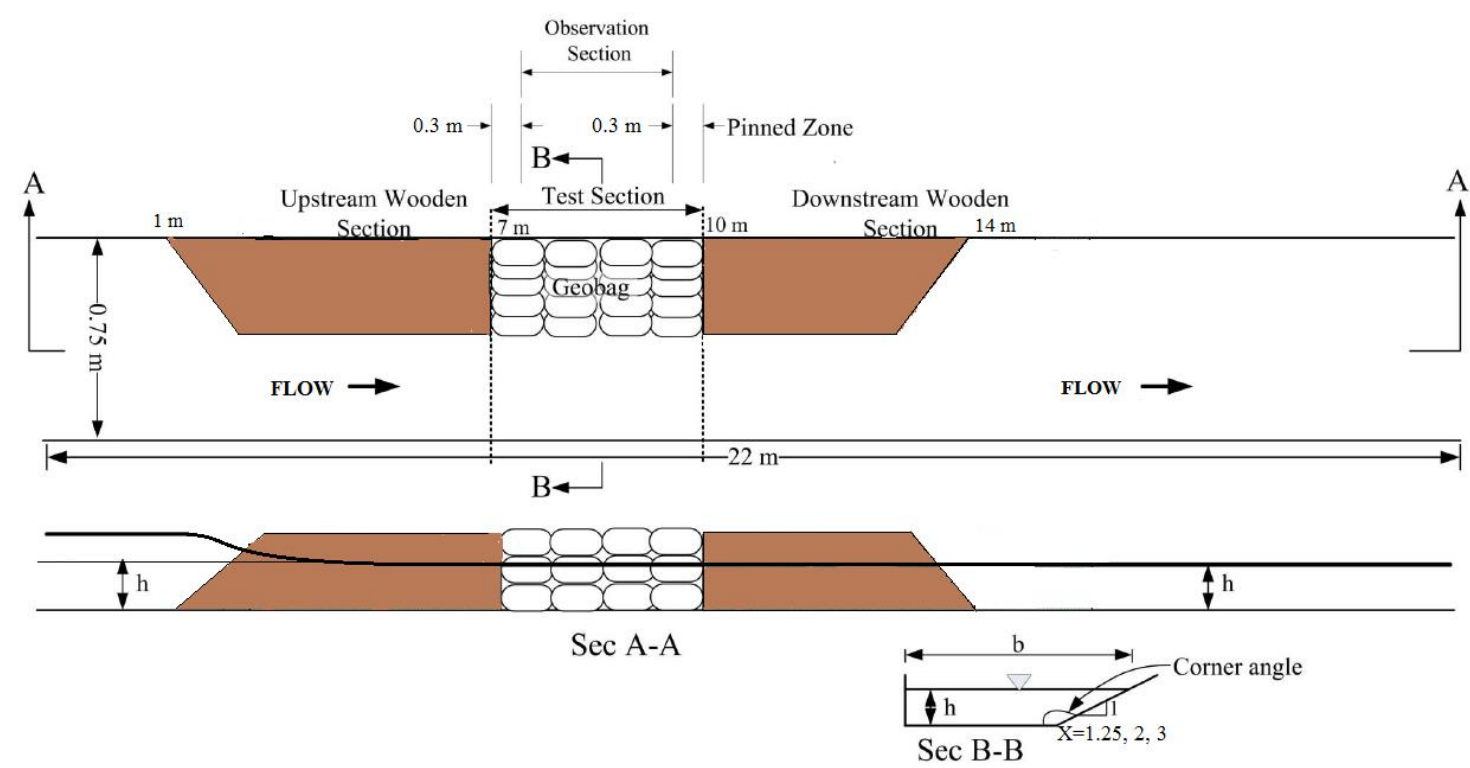

Figure 2. Experimental setup (located halfway down the flume). 
A scale of 1:10 (L) was selected based on Froude scaling criteria and the available laboratory facilities. From the Froude criteria, the velocity scale relates to the geometric scale in the proportion $\mathrm{L}^{1 / 2}$, so the relevant scale ratio was 3.17 (Table 1). As there are no defined scaling rules regarding geotextile and fill materials in small scale geobag structure models, and it was not practical to manufacture a scaled-down model of the constituent materials within the geobags (geotextile and sand), the geobags were constructed from the same material used in the field and filled with sand with a Fineness Modulus of 1.72, D50 of $0.2 \mathrm{~mm}$, and a relative density of 1.83 ; as such, it is clear that some material distortion existed in the study. Other relevant scales were computed as shown in Table 1. In the Jamuna riverbank protection work, the recommended field characteristics were geobags of dimensions $1.03 \times 0.7 \mathrm{~m}$ and $126 \mathrm{~kg}$ mass, which offered the best performance [13]. Applying a 1:10 scale, the laboratory geotextile bags, with the recommended $80 \%$ filling ratio [18], had a mass of $0.126 \mathrm{~kg}$ and dimensions of $103 \mathrm{~mm} \times 70 \mathrm{~mm} \times 10.2 \mathrm{~mm}$. The density of the dry geobag was found as $1596\left(\mathrm{~kg} \mathrm{~m}^{-3}\right)$.

Table 1. Scale Ratio for Experimental Setup.

\begin{tabular}{ccc}
\hline Quantity & Dimension & Scale Ratio \\
\hline Length, breadth & $\mathrm{L}$ & $1: 10$ \\
\hline Bag volume/mass & $\mathrm{L}^{3}$ & $1: 1000$ \\
\hline Velocity & $\mathrm{L}^{1 / 2}$ & $1: 3.17$ \\
\hline Discharge & $\mathrm{L}^{5 / 2}$ & $1: 316$ \\
\hline
\end{tabular}

To minimise the impact of the unavoidable flow contraction and expansion at either end of the observation window, wooden tapered sections were installed upstream and downstream to smooth these transitions. Additionally, to avoid turbulence driven effects at the interface between the wooden tapers and the geobag structure, and to reduce the edge effect due to this discontinuity, the surface geobags were pinned for $0.3 \mathrm{~m}$ of the test section at either end. Both measures also help better replicate field conditions, where sections of geobags are typically flanked by firmer (soil or rock) conditions.

To observe the performance of the geobag revetment under hydrodynamic loads, and to avoid the impact of toe scouring on the process of failure, the experiments were conducted under a fixed-bed condition. Experiments ran for approximately seven hours, which was sufficient time for the failure processes to stabilise, i.e., there was no further, significant geobag movement in the revetment structure. From previous studies [17], it was observed that specific failure modes (bag movements) tend to occur in different ranges of water depth (relative to revetment height). Thus, experiments were typically run under steady conditions with low, medium, and high-water depths (respectively $0-49 \%$, $50-60 \%$, and $60-80 \%$ of revetment height); to keep flow Froude numbers as constant as possible, and hence enable comparison of all results, water depths for the steepest side slope configuration were $0-30 \%, 30-40 \%$, and $40-50 \%$ of revetment height. Along with the three side slopes and two construction bonds, this resulted in a total of 18 separate experimental scenarios (Table 2). 
Table 2. Experimental flow conditions.

\begin{tabular}{|c|c|c|c|c|c|c|c|c|}
\hline $\begin{array}{l}\text { Side } \\
\text { Slope }\end{array}$ & $\begin{array}{c}\text { Water Depth } \\
\text { vs. } \\
\text { Revetment } \\
\text { Height (\%) }\end{array}$ & $\begin{array}{c}\text { Flow Rate } \\
\left(\mathrm{m}^{3} \mathrm{~s}^{-1}\right)\end{array}$ & $\begin{array}{c}\text { Mean Water } \\
\text { Depth (m) }\end{array}$ & $\begin{array}{c}\text { Mean } \\
\text { Streamwise } \\
\text { Velocity } \\
\left(\mathrm{m} \mathrm{s}^{-1}\right)\end{array}$ & $\begin{array}{l}\text { Froude } \\
\text { Number }\end{array}$ & $\begin{array}{l}\text { Reynolds } \\
\text { Number }\end{array}$ & $\begin{array}{c}\text { Initial } \\
\text { Failure Type }\end{array}$ & $\begin{array}{l}\text { Complete } \\
\text { Failure } \\
\text { Mecha- } \\
\text { nisms }\end{array}$ \\
\hline \multicolumn{9}{|c|}{ (a) Stack bond } \\
\hline \multirow{3}{*}{$1 \mathrm{~V}: 3 \mathrm{H}$} & $0-49$ & 0.024 & 0.055 & 0.95 & 1.41 & 158,801 & No movement & $\begin{array}{c}\text { No } \\
\text { movement }\end{array}$ \\
\hline & $50-60$ & 0.041 & 0.077 & 1.10 & 1.39 & 235,568 & No movement & $\begin{array}{c}\text { No } \\
\text { movement }\end{array}$ \\
\hline & $60-80$ & 0.054 & 0.090 & 1.20 & 1.41 & 287,864 & $\begin{array}{c}\text { Turbulent } \\
\text { bursting, Partial } \\
\text { uplifting, } \\
\text { Pull-out }\end{array}$ & $\begin{array}{l}\text { Pull-out, } \\
\text { Slumping }\end{array}$ \\
\hline \multirow{3}{*}{$1 \mathrm{~V}: 2 \mathrm{H}$} & $0-49$ & 0.035 & 0.067 & 1. 12 & 1.43 & 231,265 & $\begin{array}{l}\text { Turbulent } \\
\text { bursting, Partial } \\
\text { uplifting }\end{array}$ & $\begin{array}{l}\text { Full- } \\
\text { uplifting, } \\
\text { Internal } \\
\text { sliding }\end{array}$ \\
\hline & $50-60$ & 0.055 & 0.095 & 1.26 & 1.40 & 322,057 & $\begin{array}{l}\text { Pull-out, Full } \\
\text { uplifting }\end{array}$ & $\begin{array}{l}\text { Pull-out, } \\
\text { Internal } \\
\text { sliding }\end{array}$ \\
\hline & $60-80$ & 0.075 & 0.115 & 1.39 & 1.39 & 401,126 & Pull-out, Sliding & $\begin{array}{l}\text { Pull-out, } \\
\text { Sliding }\end{array}$ \\
\hline \multirow{3}{*}{$1 \mathrm{~V}: 1.25 \mathrm{H}$} & $0-30$ & 0.044 & 0.085 & 1.25 & 1.40 & 294,974 & $\begin{array}{l}\text { Uplifting, } \\
\text { Pull-out }\end{array}$ & $\begin{array}{l}\text { Pull-out, } \\
\text { Vertical } \\
\text { sliding }\end{array}$ \\
\hline & $30-40$ & 0.061 & 0.105 & 1.41 & 1.39 & 376,119 & $\begin{array}{l}\text { Pull-out, Vertical } \\
\text { sliding }\end{array}$ & $\begin{array}{l}\text { Pull-out, } \\
\text { Vertical } \\
\text { sliding, } \\
\text { Uplifting }\end{array}$ \\
\hline & $40-50$ & 0.078 & 0.122 & 1.50 & 1.40 & 450,225 & $\begin{array}{l}\text { Pull-out, Vertical } \\
\text { sliding }\end{array}$ & $\begin{array}{l}\text { Pull-out, } \\
\text { Vertical } \\
\text { sliding, } \\
\text { Uplifting }\end{array}$ \\
\hline \multicolumn{9}{|c|}{ (b) Running bond } \\
\hline \multirow{3}{*}{$1 \mathrm{~V}: 3 \mathrm{H}$} & $0-49$ & 0.023 & 0.054 & 0.95 & 1.39 & 153,241 & No movement & $\begin{array}{c}\text { No } \\
\text { movement }\end{array}$ \\
\hline & $50-60$ & 0.044 & 0.080 & 1.10 & 1.40 & 248,345 & No movement & $\begin{array}{c}\text { No } \\
\text { movement }\end{array}$ \\
\hline & $60-80$ & 0.055 & 0.091 & 1.18 & 1.41 & 291,576 & $\begin{array}{c}\text { Turbulent } \\
\text { bursting, Partial } \\
\text { uplifting, } \\
\text { Pull-out }\end{array}$ & $\begin{array}{l}\text { Pull-out, } \\
\text { Slumping }\end{array}$ \\
\hline \multirow{3}{*}{$1 \mathrm{~V}: 2 \mathrm{H}$} & $0-49$ & 0.037 & 0.074 & 1.15 & 1.41 & 240,618 & $\begin{array}{l}\text { Turbulent } \\
\text { bursting, Partial } \\
\text { uplifting }\end{array}$ & $\begin{array}{l}\text { Full- } \\
\text { uplifting, } \\
\text { Internal } \\
\text { sliding }\end{array}$ \\
\hline & $50-60$ & 0.055 & 0.095 & 1.26 & 1.40 & 322,057 & $\begin{array}{l}\text { Pull-out, Full } \\
\text { uplifting }\end{array}$ & $\begin{array}{l}\text { Pull-out, } \\
\text { Internal } \\
\text { sliding }\end{array}$ \\
\hline & $60-80$ & 0.075 & 0.113 & 1.35 & 1.40 & 393,841 & Pull-out, Sliding & $\begin{array}{l}\text { Pull-out, } \\
\text { Sliding }\end{array}$ \\
\hline \multirow{3}{*}{$1 \mathrm{~V}: 1.25 \mathrm{H}$} & $0-30$ & 0.043 & 0.084 & 1.27 & 1.40 & 289,533 & $\begin{array}{l}\text { Uplifting, } \\
\text { Pull-out }\end{array}$ & $\begin{array}{l}\text { Pull-out, } \\
\text { Vertical } \\
\text { sliding }\end{array}$ \\
\hline & $30-40$ & 0.064 & 0.108 & 1.42 & 1.40 & 389,923 & $\begin{array}{l}\text { Pull-out, Vertical } \\
\text { sliding }\end{array}$ & $\begin{array}{l}\text { Pull-out, } \\
\text { Vertical } \\
\text { sliding, } \\
\text { Uplifting }\end{array}$ \\
\hline & $40-50$ & 0.078 & 0.121 & 1.53 & 1.42 & 451,922 & $\begin{array}{l}\text { Pull-out, Vertical } \\
\text { sliding }\end{array}$ & $\begin{array}{l}\text { Pull-out, } \\
\text { Vertical } \\
\text { sliding, } \\
\text { Uplifting }\end{array}$ \\
\hline
\end{tabular}

Before the commencement of each test, the weights of the individual surface geobags were measured to ensure that all individual experiments were run with relatively dry bags (moisture content less than $0.5 \%$ ). At the end of each test, the number of bags that were displaced from the revetment and settled at the end of the flume (washed away geobags) 
was recorded. To ensure representative results, each test was repeated at least two times, with a third test undertaken if the results from the first two differed significantly.

\subsection{Revetment Side Slopes}

Three different side slopes $(1 \mathrm{~V}: 1.25 \mathrm{H}, 1 \mathrm{~V}: 2 \mathrm{H}$, and $1 \mathrm{~V}: 3 \mathrm{H})$ were tested to investigate the impact of side slope on stability and failure mode. These side slopes provided revetment dimensions of $0.375 \mathrm{~m}$ width and $0.30,0.18$, and $0.125 \mathrm{~m}$ height respectively. For both construction bonds (Section 3.3), the number of geobags used for each revetment was 620, 730 , and 810 , respectively.

\subsection{Construction Bond}

To determine the impact of construction bonds on revetment performance, two different bonds were tested (Figure 3), a stack bond ( $0 \%$ longitudinal overlap) and a running bond ( $50 \%$ longitudinal overlap). Per accepted practice and the results of previous field studies [2], geobags were placed with the longest axis in the stream-wise direction for both construction methods, and with transverse overlaps varying between $50 \%$ and $60 \%$ depending on revetment slope. The performance of these two construction bonds was evaluated, based on their longitudinal overlap.

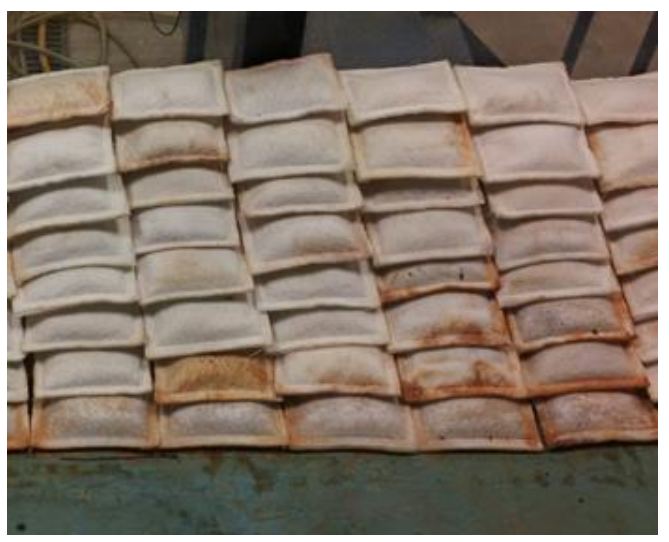

(a) Stack bond

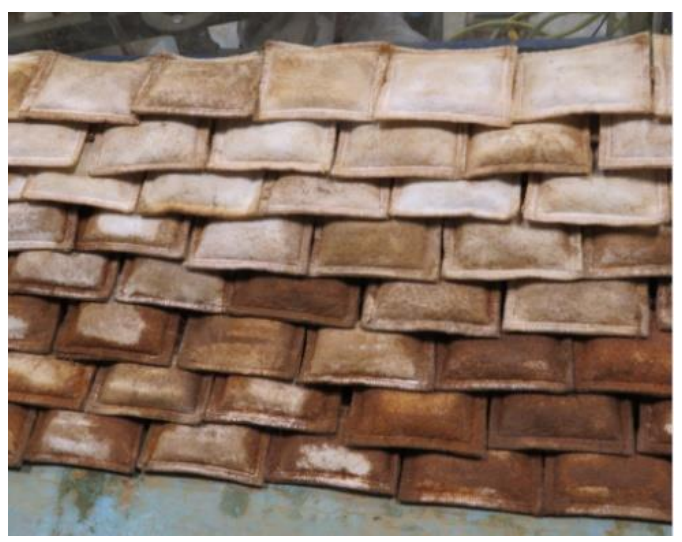

(b) Running bond

Figure 3. Revetment construction.

\subsection{Velocity Measurement}

General velocity data were collected using a side-looking Acoustic Doppler Velocimeter (ADV) at $0.10 \mathrm{~m}$ intervals in the streamwise direction, at $20 \%, 40 \%, 60 \%$, and $80 \%$ of the water depth below the surface. These data were used to calculate mean velocities using the three-point method [19], i.e., the average of the values at $0.2,0.6$, and 0.8 of the depth.

\subsection{Failure Zones}

Photogrammetry software was used to analyse 100 digital photos to develop a mesh-based image of the revetments after failure, which could be used to identify the failure-induced change in revetment geometry.

\section{Results and Discussion}

\subsection{Failure Processes}

Failure processes for the combination of three side slopes and two construction methods were observed through 18 experimental runs under different flow conditions (Table 2), to evaluate the hydraulic stability of a revetment as a function of water level and flow velocity. According to the Froude and Reynolds numbers outlined in Table 2, the flow in the flume was supercritical and turbulent for all model test runs. Although the flow regime is beyond the normal river flow regime, preliminary experimental test results and previous 
work $[17,20]$, confirmed that supercritical and highly turbulent flow regimes allowed easier simulation and observation of failure modes in the laboratory. Furthermore, these flow conditions replicate the type of flood events that are characterised by a high Froude number and supercritical flows when riverbank protection is most required [15].

Figure 4 shows a temporal analysis of events and failures in the form of a hydrograph, illustrating flow initialisation, steady-state attainment, failure initialisation, modes of failure, the end of failure, and the number of bags washed away for the high-water level condition. This figure shows that stability is directly related to side slope, with a slope of $1 \mathrm{~V}: 3 \mathrm{H}$ being significantly more stable than a slope of $1 \mathrm{~V}: 1.25 \mathrm{H}$.

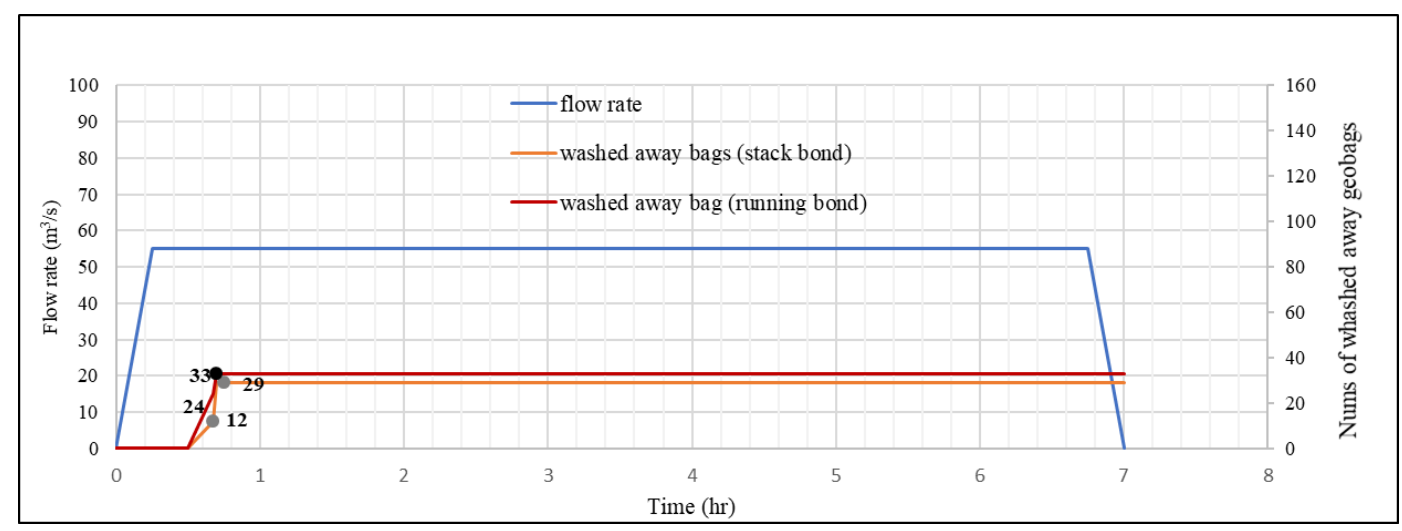

(a) side slope $1 \mathrm{~V}: 3 \mathrm{H}$

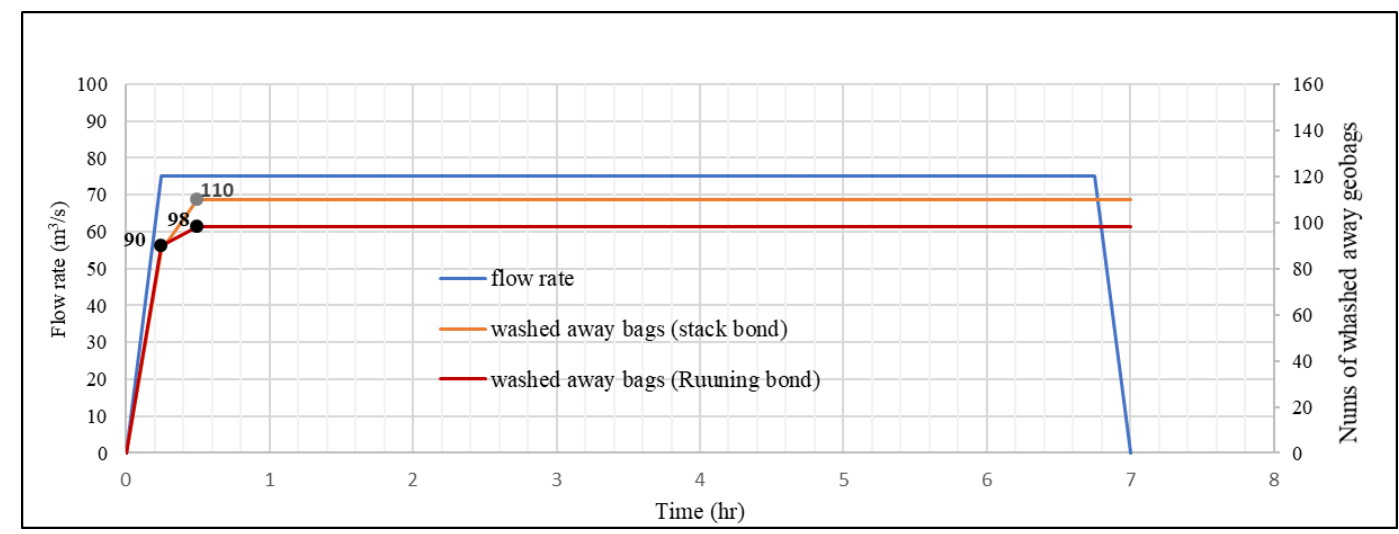

(b) $1 \mathrm{~V}: 2 \mathrm{H}$

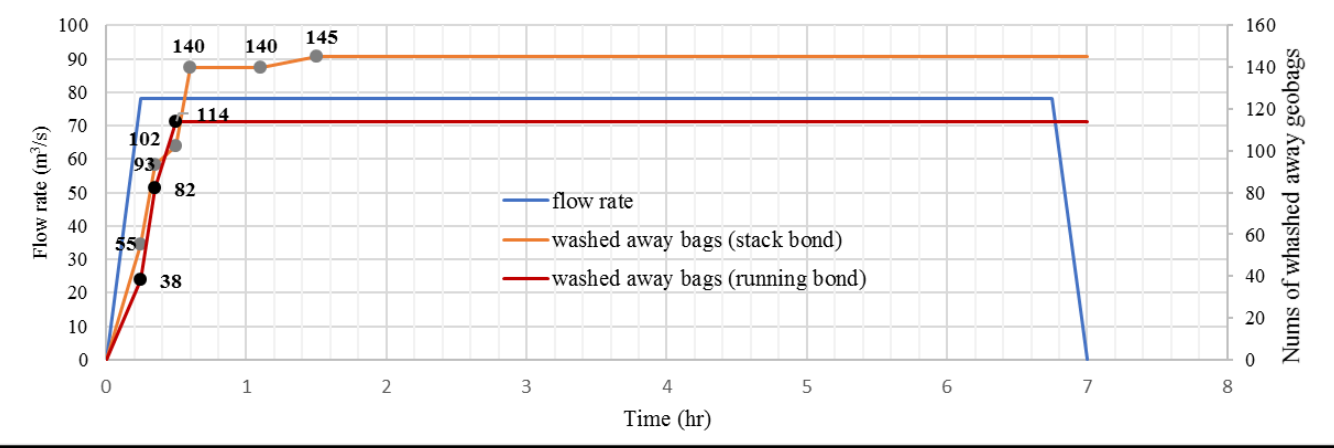

(c) $1 \mathrm{~V}: 1.25 \mathrm{H}$

Figure 4. Temporal analysis of failure processes (water depths $60-80 \%$ of revetment height). 


\subsection{Failure Mechanisms}

Failure mechanisms progressed with increasing flow velocity in and around the bag voids, which led to an increase in associated hydrodynamic forces (drag force, lift force), subtly altering the balance with the other forces (buoyancy, bag self-weight).

The three main types of displacements observed were uplifting, pull-out, and sliding.

\subsubsection{Failure due to Uplifting}

Generally, uplifting is a rotational displacement of geobags in the upward direction, and full uplifting occurs when flow-induced loads on geobags are much larger than the resisting force.

According to Equation (5), uplifting of a geobag occurs when mobilising moments (due to hydrodynamic forces) around the rotation point are large enough to overcome the resisting moments (due to the weight of the geobag). The rotation point is a virtual point (in the vertical plane) that is located at the end edge of the contact area of the geobag with the adjacent geobag underneath, or bed of the flume. Regarding Figure 5a, uplifting of the geobag can be described as:

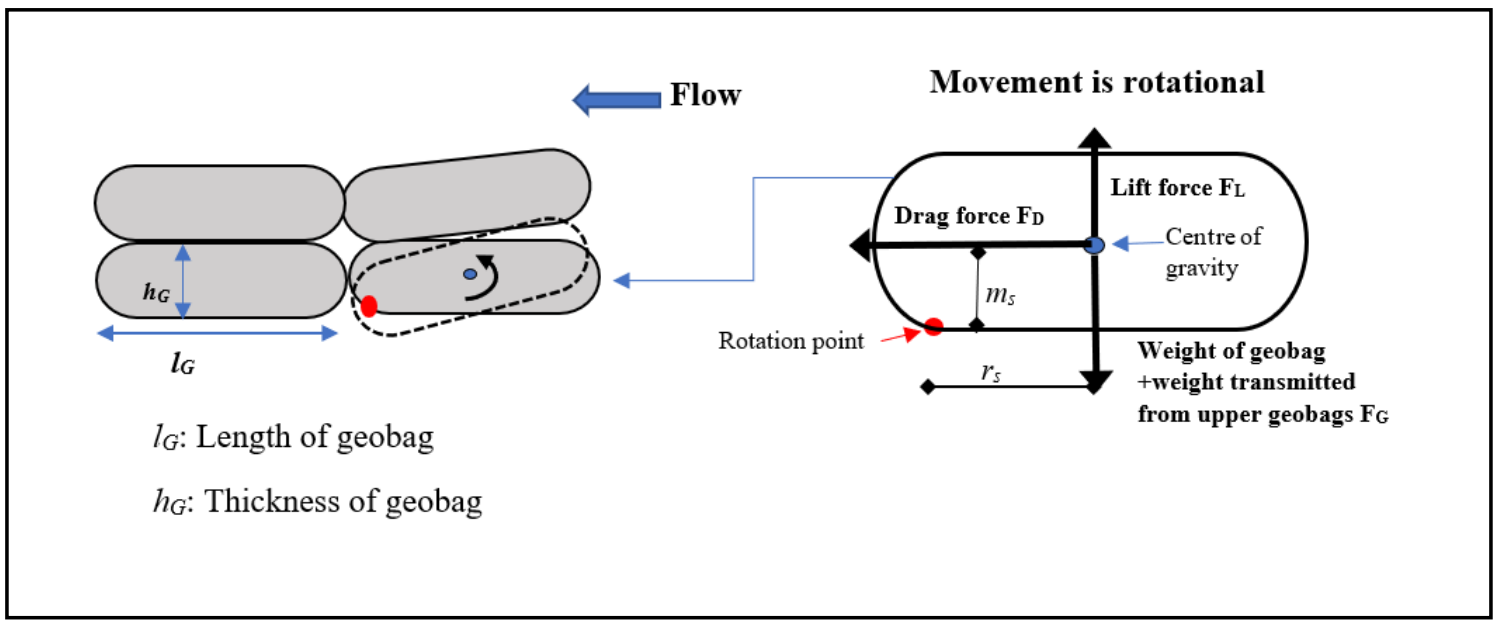

(a) Definition sketch for the uplifting of a geobag

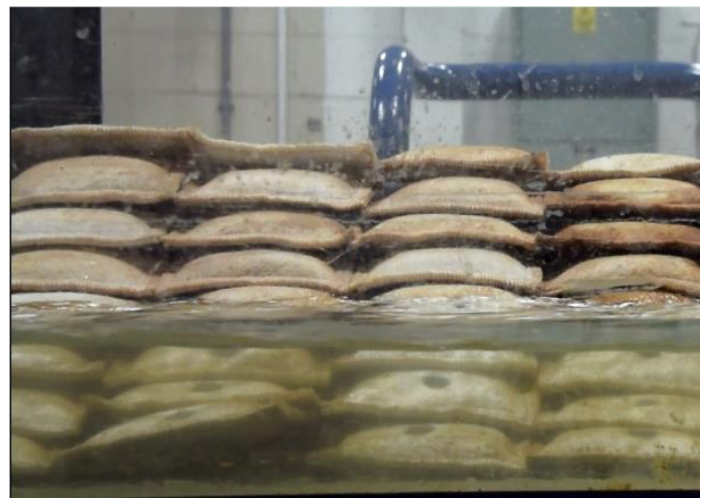

(b) Displacement due to partial uplifting

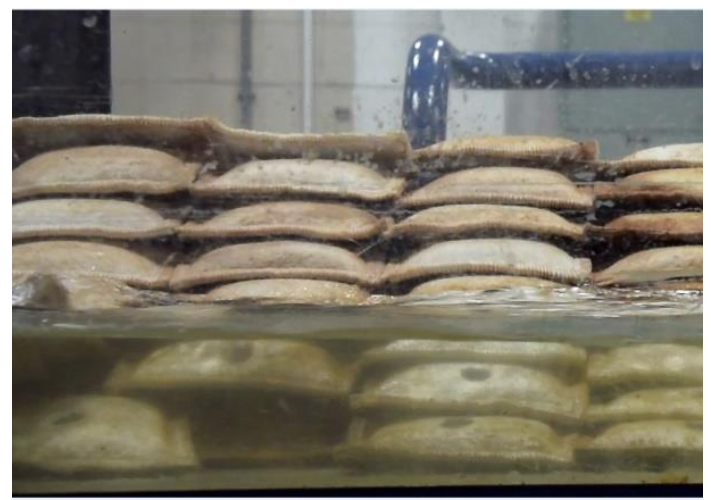

(c) Pressure difference between main flow and void flow

Figure 5. Failure due to uplifting.

Destabilising moments $\geq$ Stabilising moments:

$$
\underbrace{\left(F_{D} \cdot m_{s}\right)+\left(F_{L} \cdot r_{s}\right)}_{\text {Destabilising Moment }} \geq \underbrace{\left(F_{G} \cdot r_{s}\right)}_{\text {Stabilising moment }}
$$


where $r_{s}$ is the horizontal distance between the centre of gravity of the geobag and the rotation point, and $m_{s}$ is the vertical distance between the geobag's centre of gravity and the rotation point.

When destabilising moments on the left side of Equation (5) increase, due to turbulent bursting-induced flow through the revetment voids (Figure $5 \mathrm{~b}$ ) or an increase in flow velocity and water depth, partial or full uplifting occurs, which results in instability of the geobag. At relatively low water levels, bag displacements were usually due to turbulent bursting-induced flow through the revetment voids, which tended to lead to partial uplifting. With increasing water levels, full upliftings associated with local vortices were the typically observed failure modes.

\subsubsection{Failure Due to Pull-Out}

Pull-out frequently occurred with geobags located near the water surface. Here, higher flow velocities caused the incident hydrodynamic forces to become large enough to displace the geobags, and typically manifested itself in a clockwise rotation in the horizontal plane (Figure $6 a, b$ ). This type of displacement occurred only if the flow-induced loads on the geobags were much larger than the resisting force. According to Dassanayake [21], this resisting force is highly dependent on the weight and frictional properties of geobags, i.e., surface roughness and the contact area between geobags.

Equation (6) addresses the friction force as a function of normal loads and proportional to the friction coefficient (measured from direct shear tests [21].

$$
\begin{gathered}
\text { Friction }=F_{\text {Resisting }}=\mu\left(F_{G}-F_{L}\right) \\
\underbrace{\left(F_{D} \cdot n_{s}\right)}_{\text {Destabilising Moment }} \geq \underbrace{\left(\mu\left(F_{G}-F_{L}\right) \cdot n_{s}\right)}_{\text {Stabilising moment }}
\end{gathered}
$$

where $n_{s}$ is the transverse distance between the centre of gravity of the geobag and the rotation point (Figure $6 a, b)$.

This force acts as resistance against pull-out forces. According to Equations (6) and (7), pull-out of a geobag occurs when mobilising moments (due to hydrodynamic forces) around the rotation point (Figure 6) are large enough to counter the resisting moments (due to friction forces). In the case of pull-out, the rotation point is a virtual point (in the horizontal plane), which is located at the inner edge of the contact area of the geobag with the adjacent geobag underneath, or bed of the flume.

\subsubsection{Failure Due to Sliding and Slumping}

Figure 7 shows the definition sketch for the sliding of geobags used to protect a riverbank; in this figure, the flow direction is into the paper. Sliding and slumping were observed in all cases but were most prominent in the failure processes for high-water level conditions (Figure $7 \mathrm{~b}$ ) and steepest side slope 1V:1.25H (Figure 8c). These types of displacement were highly progressive and occurred when the gravitational force on a bag (i.e., geobag weight) was higher than the resisting force on a bag (i.e., friction). Typically, geobags above the water surface were most vulnerable to sliding, both because of higher normal loads and the failure of submerged supporting bags. 


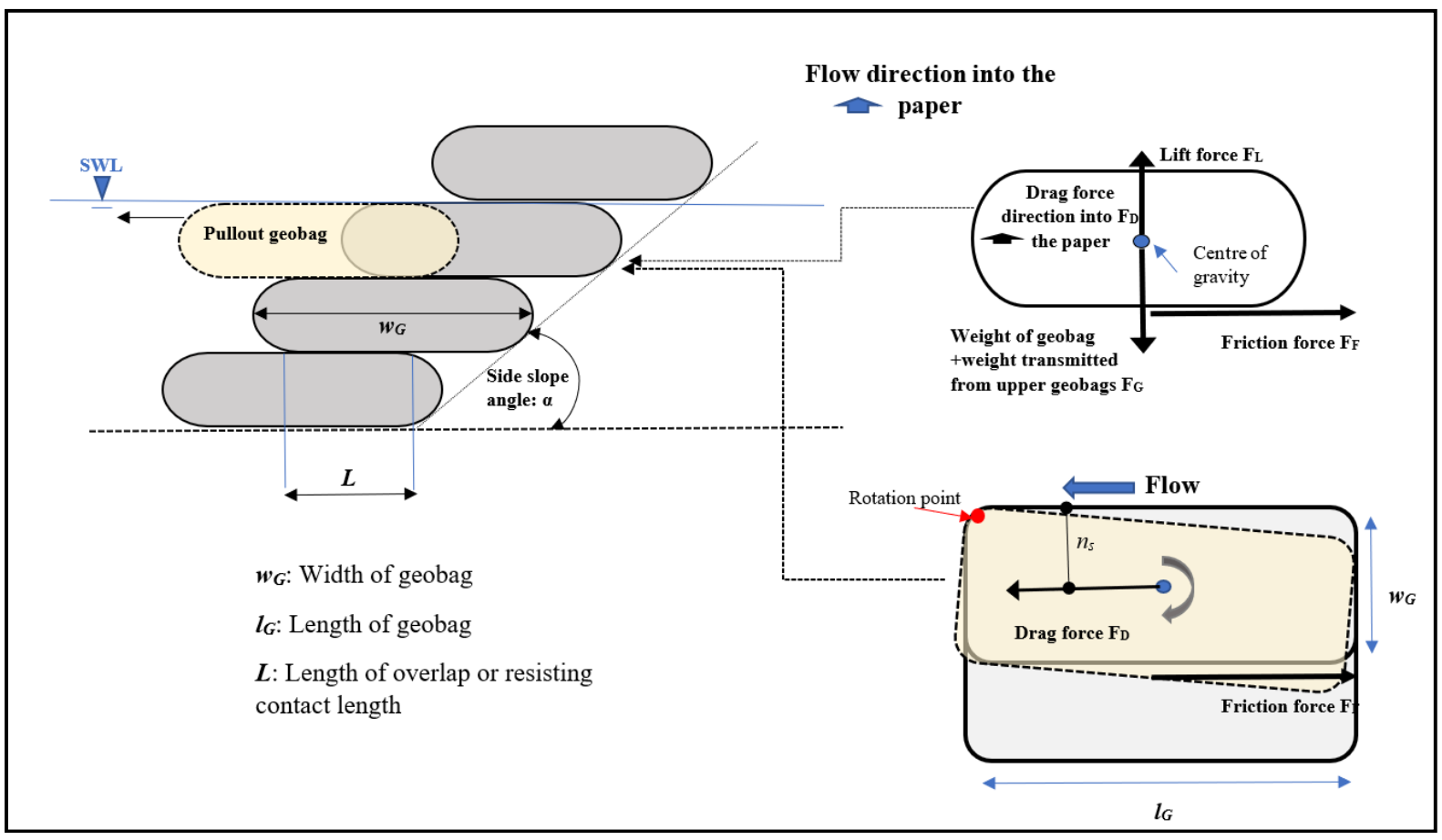

(a) Definition sketch for pull-out of a geobag

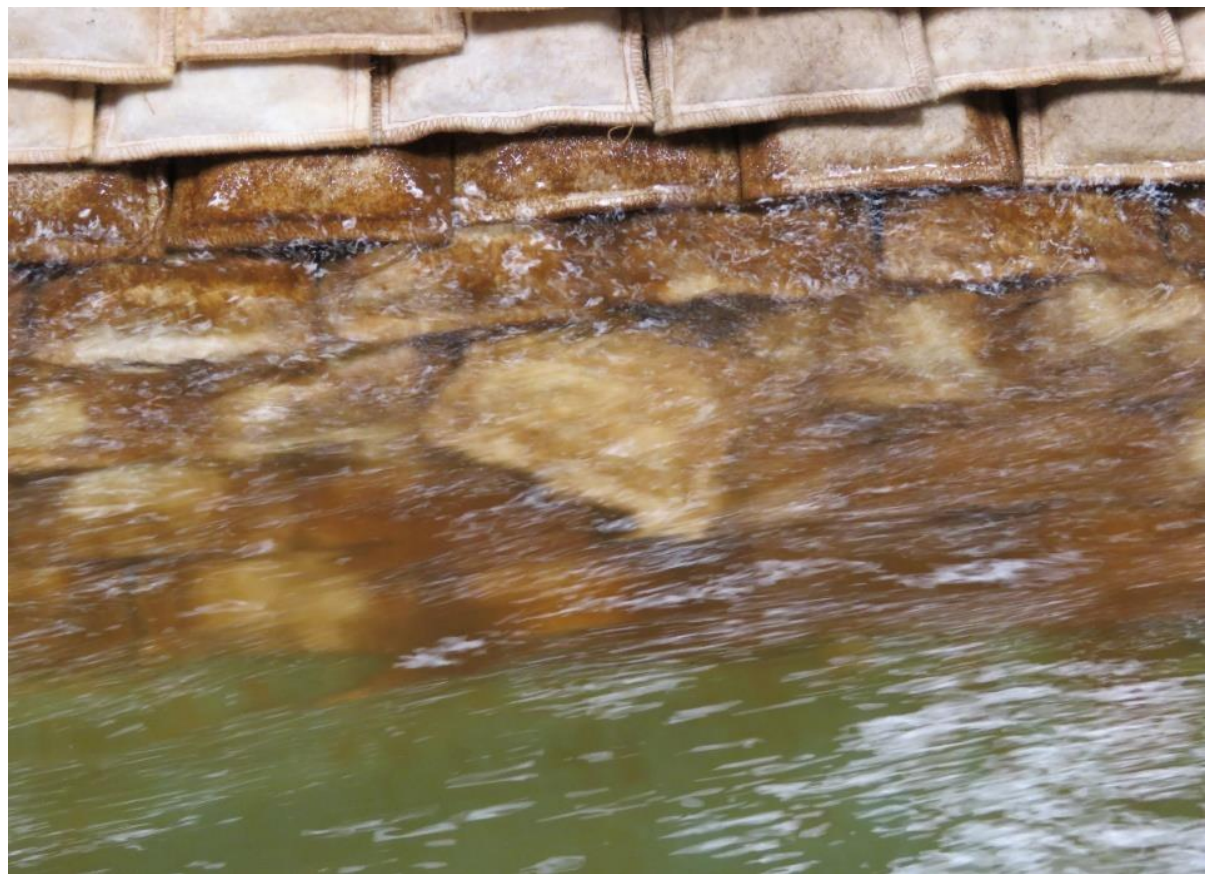

(b) Pull-out of a geobag from a layer close to water surface

Figure 6. Failure due to pull-out. 


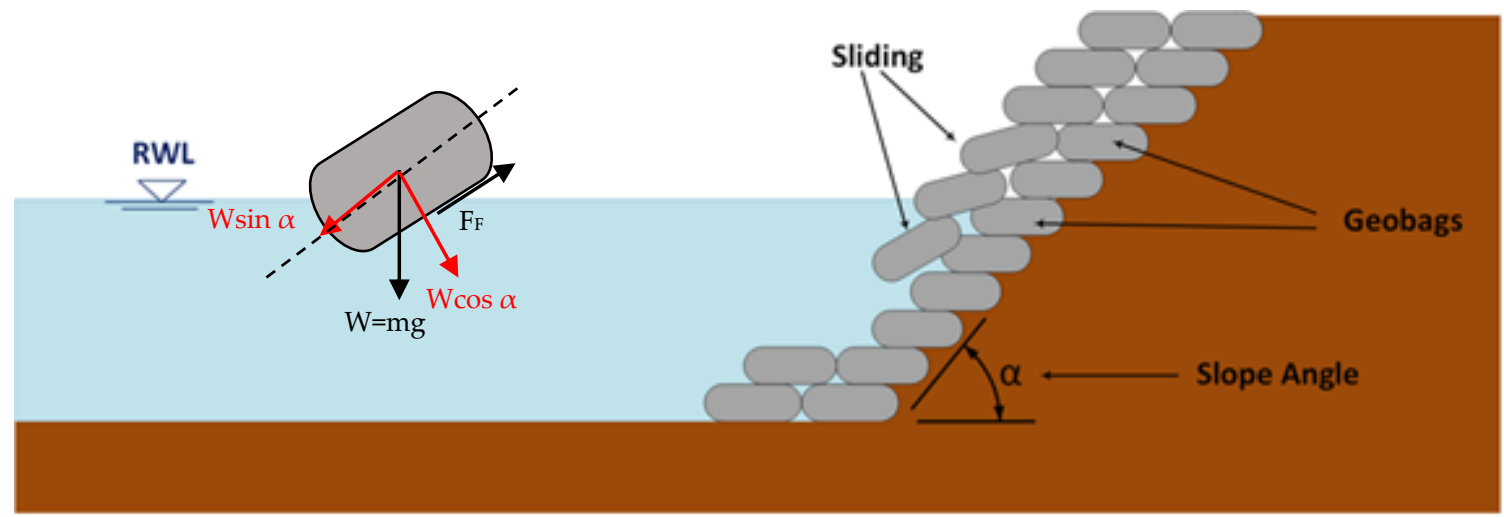

(a) Definition sketch for sliding of a geobag

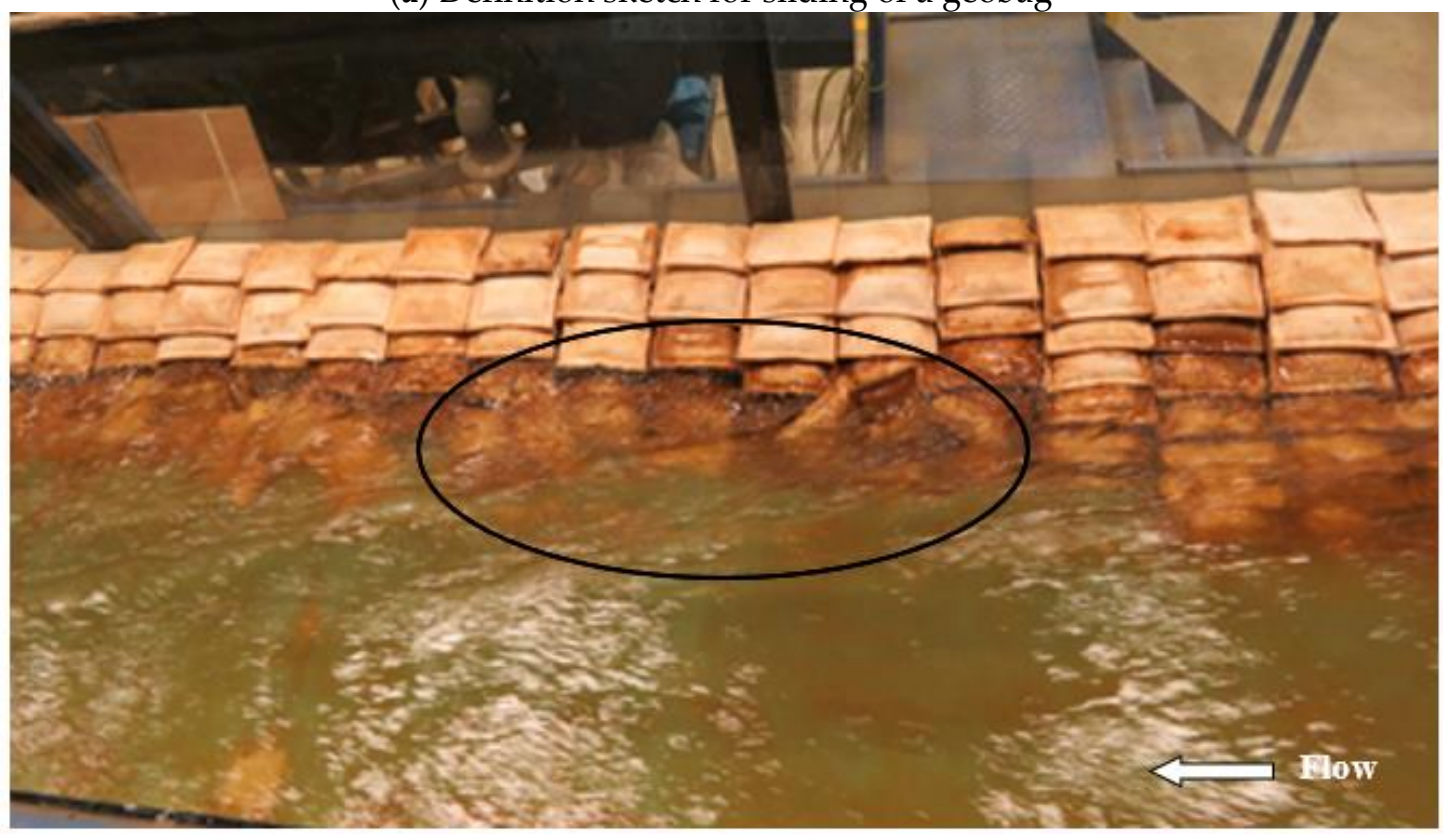

(b) Sliding of geobags in high-water level condition, side slope 1V:2H

Figure 7. Failure due to sliding.

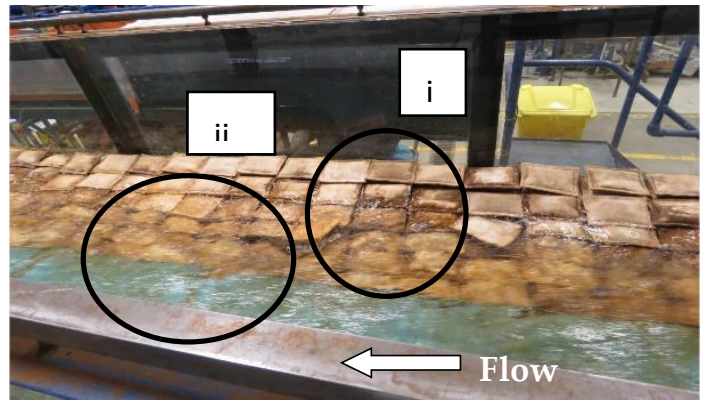

(a1) Initial displacement due to pull-out (i) and uplift (ii) in the layer close to water surface

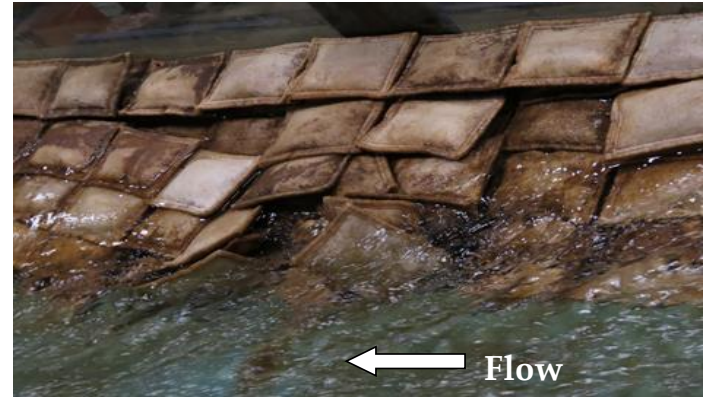

(a2) Slump of upper layer bags on the bottom layer

(a) Side slope 1V:3H (water depth 0-49\%)

Figure 8. Cont. 


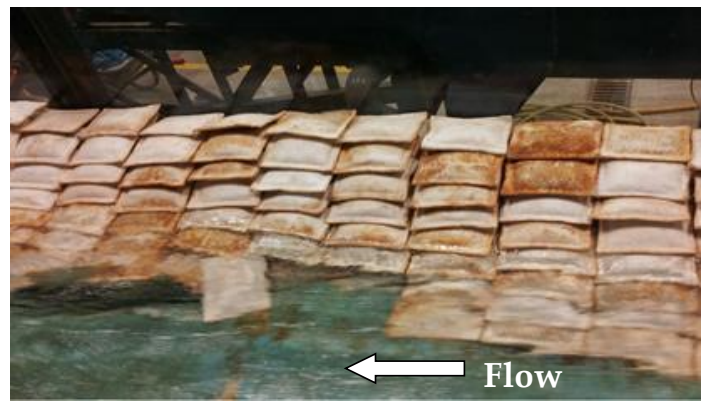

(b1) Partial uplifting and pull-out

(b) Side slope 1V:2H (water depth 50-60\%)

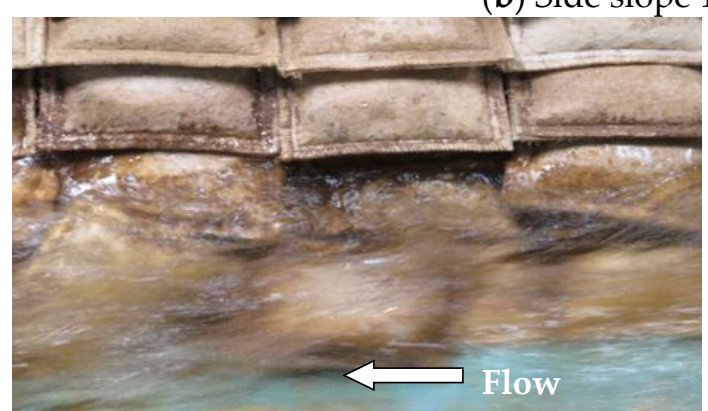

(c1) Partial uplifting, turbulent bursting-induced flow through revetment voids, and sliding

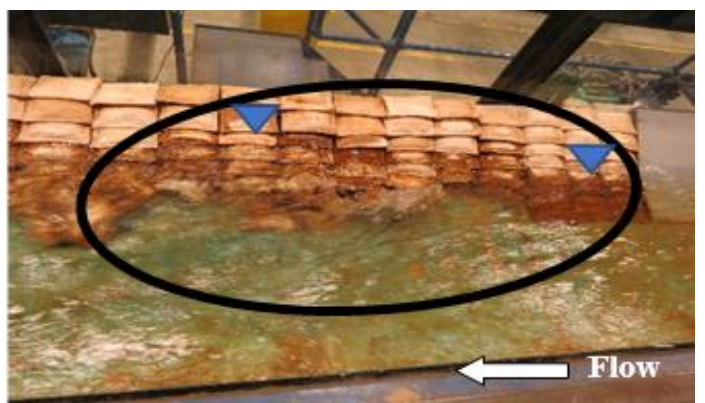

(b2) Local change in water depth due to clump of collapsed bags

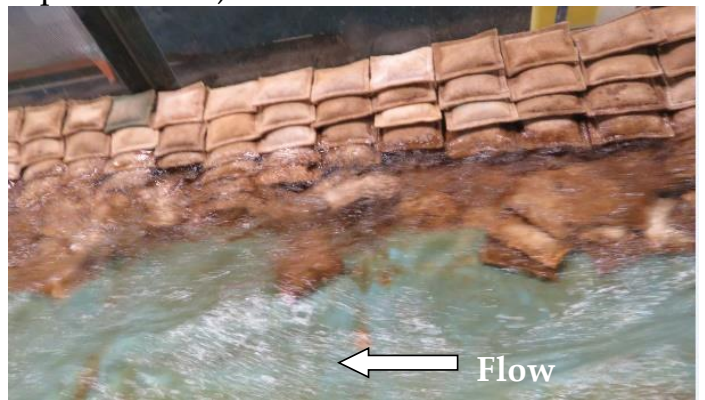

(c2) Magnitude of revetment failure at the beginning of the test due to vertical sliding

(c) Side slope 1V:1.25H (water depth 60-80\%)

Figure 8. Failure processes in geobag revetment for stack bond.

Due to the difference in normal loads, sliding under dry (above the water surface) and submerged conditions is different. When geobags are submerged, normal loads are smaller due to buoyancy; consequently, sliding forces are also smaller.

As expected, geobags in revetments with steeper side slopes demonstrated lower resistance to sliding forces (Figure 7a). This is mainly because the mobilising force (Wsin $\alpha$ ) is closer to the line passing through the centre of gravity, so it overcomes friction $\left(\mathrm{F}_{\mathrm{F}}\right)$ and sliding is more probable. In contrast, slumping was mostly seen in the case of milder side slopes where the perpendicular component of the geobag weight vector was large enough to let the geobags vertically collapse. In this case, the geobag weight component parallel to the slope is not in line with the centre of gravity (Figure 8).

\subsection{Impact of Varying Hydrodynamic Load (Water Depth)}

In general, the failure processes for all experimental runs and for varying water depths were completed through combinations of failure modes, such as, turbulent burstinginduced flow through the revetment voids (usually outward movements of bags), partial or full uplifting, pull-out (ejections of bags), and sliding (Table 2).

Observations indicated that failure mechanisms were significantly influenced by water level. At relatively low water levels, bag displacements were usually due to turbulent bursting-induced flow through the revetment voids, which tended to lead to partial uplifting (Table 2) and (Figure 8(b1)). In moderate- to high-water levels, the typical observed failure modes were full uplifting associated with pull-out processes (Table 2).

Sliding and slumping was commonly observed in all cases; however, they characterised the failure process in high-water level conditions where bottom layer bags were washed away quickly from the test section and upper layer bags collapsed due to sliding (Figure $8(\mathrm{a} 2, \mathrm{c})$ ). Therefore, in these cases, sliding was considered a secondary failure mode. 


\subsection{Impact of Side Slope}

The experimental data indicate that revetment stability is strongly dependent on side slope. The mildest side slope revetments $(1 \mathrm{~V}: 3 \mathrm{H})$ were noticeably more stable, with no bag movement for low and medium water levels and, whilst failure under high depth conditions was observed in the layer of bags at the water surface, no bags were washed away from the bottommost layer. Typically, in the case of the mildest side slope, and for both construction methods, partial and full uplifting associated with pull-out were the most common initial failure modes (Figure 8a). Interestingly, as failure progressed, the slump of the top layers of bags over the bottom layer appeared to help the revetment remain stable and prevent the failure zone expanding (Figure 8(a2)).

As shown in Figure $8 \mathrm{~b}$ and Table 2, for both construction bonds with a side slope of $1 \mathrm{~V}: 2 \mathrm{H}$ and low to medium water depth, the geobag layers below the water surface tended to fail due to pull-out, uplifting, and turbulent bursting, and followed a similar process to that observed for initial revetment failure [17]. In addition, the failure process created a clump of collapsed bags, which itself led to a localised increase in upstream water depth. Whilst this phenomenon exposed the upper layers of the geobags to the flow, it also decreased local flow velocities in this area, which seemed to prevent more upstream bags from being washed away (Figure 8(b2)). Moreover, this failure mechanism affected downstream flow conditions by reducing flow acceleration in front of the revetment, hence helping downstream geobags to remain stable. For the high-water level condition, vertical sliding failure, initiated with the failure of the submerged supporting bags, was also observed in the layers above the water surface.

In comparison with the other side slopes, the failure processes for revetments with the steepest slope (1V:1.25H) progressed rapidly (Figure 8c). Although, with relatively dry geobags, failure usually started with the bag pull-out processes associated with higher stream-wise velocities, vertical sliding also played an important role in failure progression. Moreover, turbulent bursting-induced flow through the revetment voids, because of water pressure differences between the channel side and the geobag lee side and other failure modes (e.g., uplifting), were commonly observed during the failure process in almost all water depths.

\subsection{Impact of Construction Bond}

Experimental results indicate that failure mechanisms depend on both water depth and revetment slope but, somewhat surprisingly, were found to be generally independent of the specific geobag bond configuration. With no mortar-like bonding between individual geobags, the integrity of a revetment under any particular slope/depth scenario was found to be dependent on the contact area between individual geobags, which can be considered a proxy for frictional resistance, rather than the precise bond configuration. Figure 9 illustrates this finding by demonstrating that the number of bags displaced from the revetment was relatively unaffected by construction bonds. This point is confirmed by the data provided in Figure 4, which illustrates the temporal change in bags washed away and indicates the noticeable impact of side slope over bond configuration. 


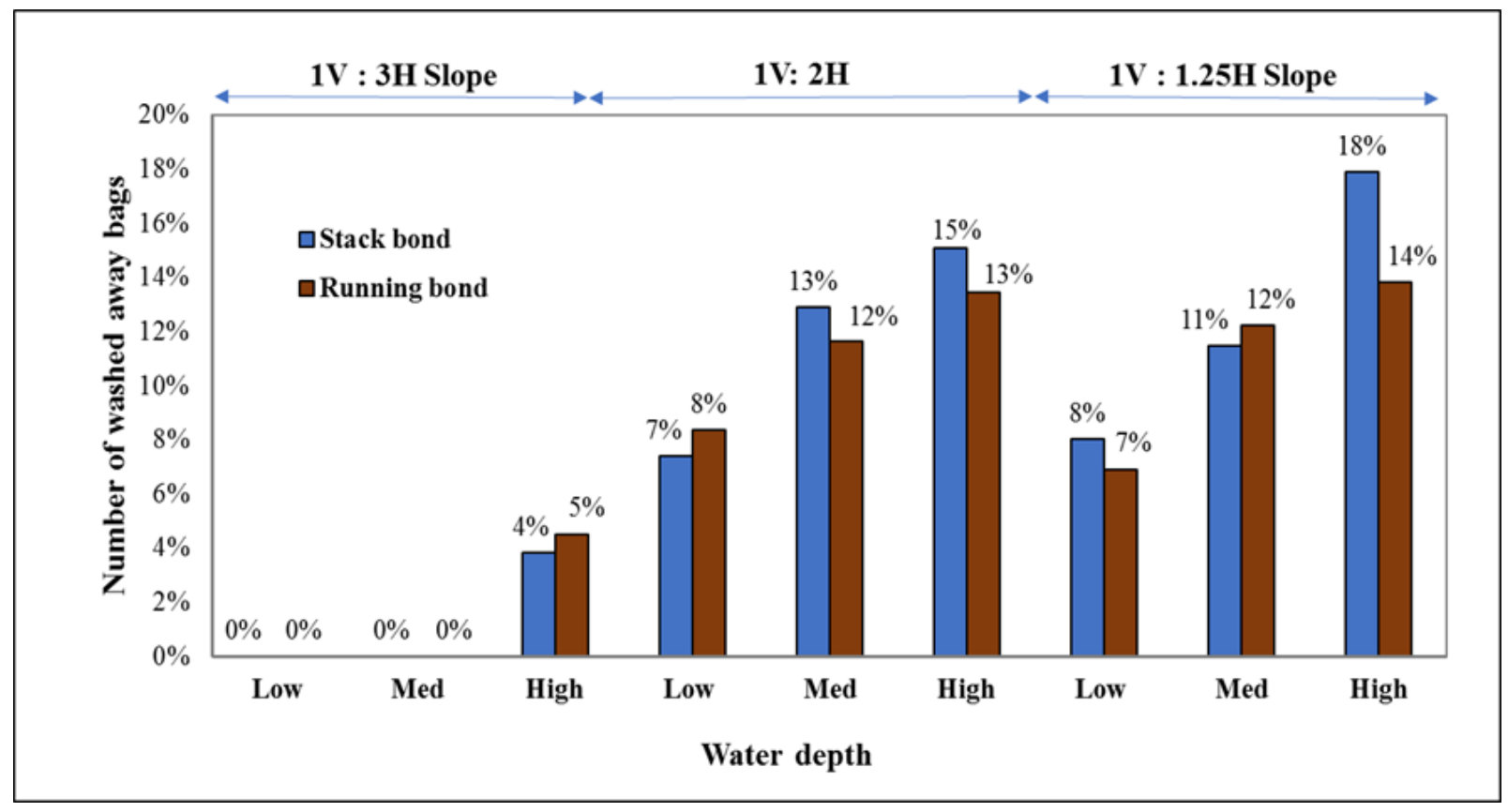

Figure 9. Average percentage of washed away bags at the end of each test.

\subsection{Failure Zones}

The failure zone for any revetment can be defined as the area of the revetment influenced by failure processes, and the dimensions of a failure zone can be used to estimate the magnitude of damage. Figure 10 demonstrates the worst-case scenario for each revetment side slope (under the high-water level condition) based on the size of the failure zone. These images were produced using photogrammetry software to analyse 100 digital photos to develop a mesh-based image of the revetments after failure, which could be used to identify the failure-induced change in revetment geometry. As shown in Figure 10c, a steeper side slope results in a larger and deeper failure zone.

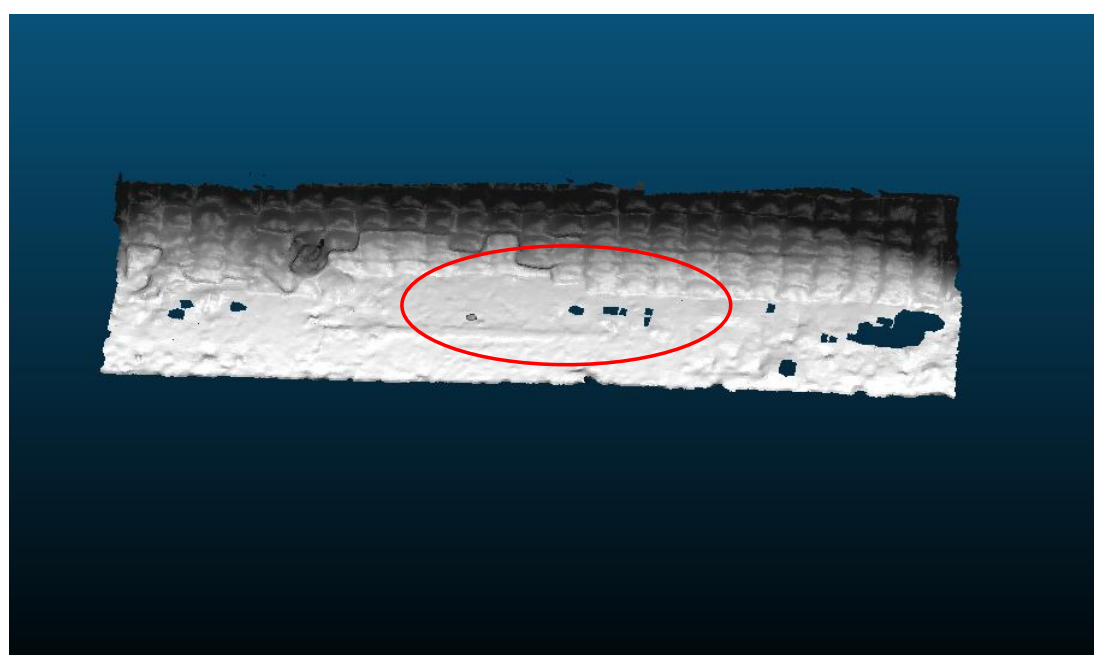

(a) 1V: $3 \mathrm{H}$ side slope

Figure 10. Cont. 


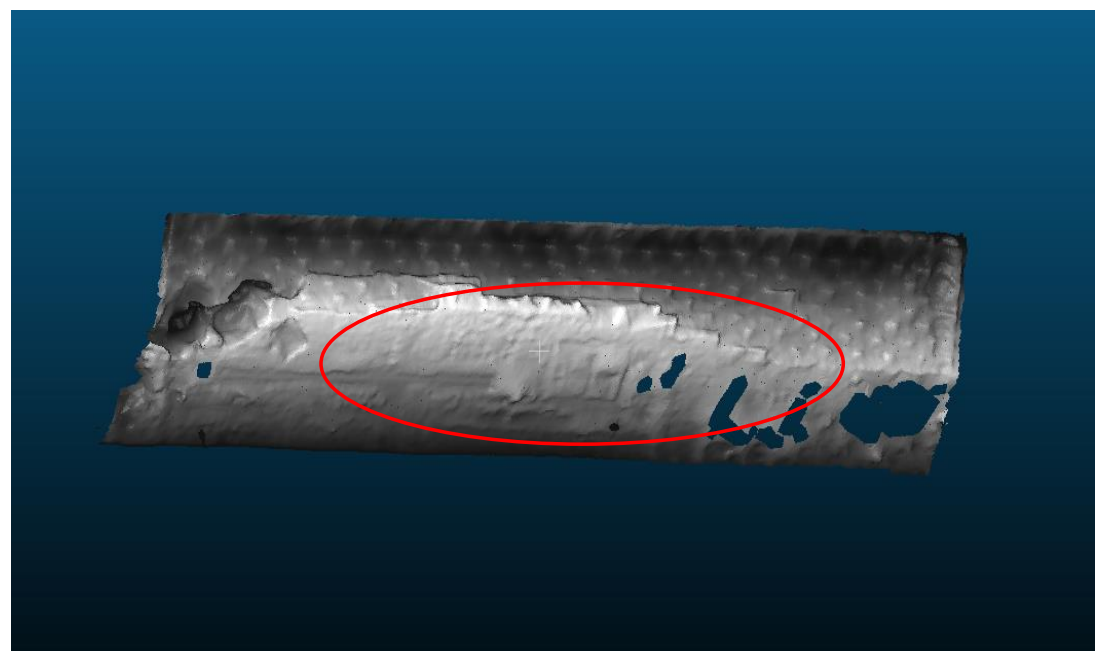

(b) 1V: 2H side slope

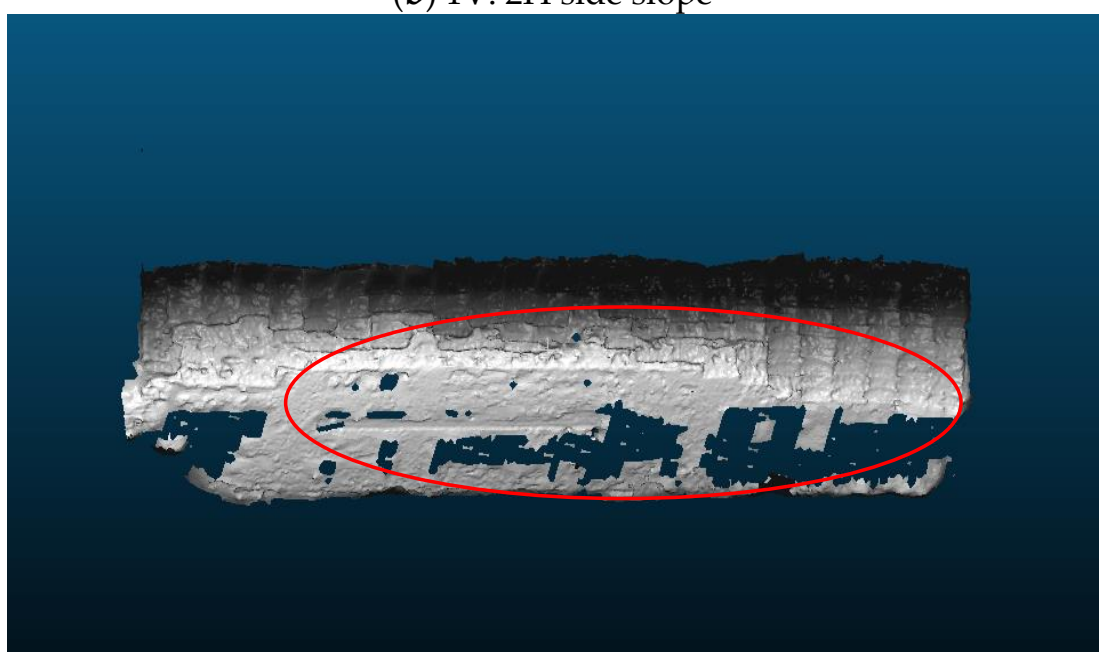

(c) $1 \mathrm{~V}: 1.25 \mathrm{H}$ side slope

Figure 10. Failure zones for different side slopes. Note that the "holes" shown in the meshes are due to the lack of sufficient image overlap.

\subsection{Summary}

The failure mechanisms described in this paper provide details of different failure modes that can occur in a geobag revetment in rivers, based on hydrodynamic forces analysis. Throughout the complete failure processes, the observed failure modes for each condition were:

- $\quad$ Side slope 1V:3H: Typically, in the case of mildest side slope and for both construction methods, partial and full uplifting associated with pull-out were the most common initial failure modes.

- $\quad$ Side slope 1V:2H: For both construction bonds and low to medium water depth conditions (A and B), the geobag layers tended to fail due to pull-out, dislodgement, uplifting and turbulent bursting. Vertical sliding failure, initiated with the failure of the submerged supporting bags, was also observed in the layers above the water surface for the high-water level condition. These findings are in line with the conclusions of NHC [13] and Akter et al [17], which demonstrated the experience of similar incipient failure mechanisms in the field and laboratory, respectively.

- Side slope 1V:1.25H: Vertical sliding played an important role in failure progression in the case of the steepest slope. Moreover, turbulent bursting-induced flow through the revetment voids, combined with other failure modes (e.g., uplifting), were commonly observed during the failure process in almost all water level conditions. 


\section{Conclusions}

This paper has presented an analysis of the results of a distorted-scale laboratory investigation of geobag revetment performance, with particular emphasis on complete failure processes. Such analysis helps to predict the behaviour of a geobag revetment while it is exposed to different flow conditions and/or construction specifications. However, the distorted-physical model used for laboratory experiments had the following limitations:

- Scale effects that existed due to the physical model.

- The fixed-bed nature of the experimental work, which helped isolate the impact of hydrodynamic loadings, meant that the impact of toe scour could not be incorporated.

Despite the above limitations, the distorted-physical model provided important data regarding the performance of geobag revetment in rivers. In conclusion, the complete failure mechanisms are characterised by a combination of turbulent bursting, partial or full uplifting, pull-out, and sliding. Experimental results also indicate that failure mechanisms depend on both water depth and revetment slope but were found to be generally independent of the specific geobag bond configuration. It can thus be concluded that the dominating factor is the friction between individual geobags, which itself is dependent on bag longitudinal overlap rather than specific construction method. This finding has important implications for revetment construction methods, since, in the field, different placement methods (e.g., riverbank launching, pontoon launching) can lead to a wide range of different construction bonds [15] and there are no precise rules for achieving target construction bonds among revetment while constructed [3]. This finding also highlights that present launching practices do not affect the hydraulic stability of geobag revetments within this scope.

In addition to new insights into the performance of geobag revetments in the fluvial environment, the outcomes from this study have been used to develop a Discrete Element Model (DEM) of geobag revetments; such a model is a key steppingstone in the development of improved revetment design guidelines.

Author Contributions: Conceptualization, L.K., G.W., M.C.; methodology, L.K., G.W., M.C.; software, L.K.; validation, L.K., G.W., M.C.; formal analysis, L.K., G.W., M.C.; investigation, L.K., G.W., M.C.; resources, G.W., M.C.; data curation, L.K.; writing-original draft preparation, L.K., G.W., M.C.; writing-review and editing, L.K.; G.W., M.C.; visualization, L.K.; supervision, G.W., M.C.; project administration, G.W.; funding acquisition, G.W., M.C. All authors have read and agreed to the published version of the manuscript.

Funding: This research received no external funding.

Data Availability Statement: Data is contained within the article.

Acknowledgments: This study has been funded by the Institutes for Infrastructure and Environment at Heriot-Watt University and the University of Edinburgh, with additional support provided by NAUE Gmbh \& Co. Their support is gratefully acknowledged.

Conflicts of Interest: The authors declare no conflict of interest.

\section{Notation}

$A_{S} \quad$ cross area normal to the flow $\left(\mathrm{m}^{2}\right)$

$A_{t} \quad$ projected area of the geobag in the flow direction $\left(\mathrm{m}^{2}\right)$

$C_{L} \quad$ Coefficients of lift force (-)

$C_{D} \quad$ Coefficients of drag force (-)

$C_{M} \quad$ Coefficients of inertia (-)

$F_{A} \quad$ Buoyancy Force $(\mathrm{N})$

$F_{D} \quad$ Drag force $(\mathrm{N})$

$F_{G} \quad$ Gravitational force (N)

$F_{L} \quad$ Lift force (N) 


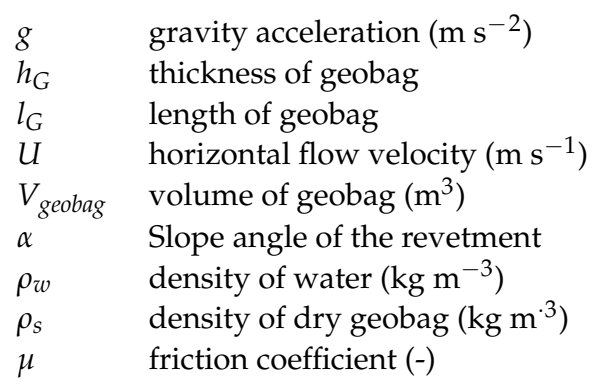

\section{References}

1. Yang, S.Q.; Shu, Y.M.; Yang, X.C. Flume experiment and numerical analysis for bank reinforcement with geocontainer. In Geosynthetics in Civil and Environmental Engineering; Springer: Berlin, Germany, 2008; pp. 630-636.

2. Zhu, L.; Wang, J.; Cheng, N.-S.; Ying, Q.; Zhang, D. Settling distance and incipient motion of sandbags in open channel flows. J. Waterw. Port Coast. Ocean Eng. 2004, 130, 98-103. [CrossRef]

3. Bangladesh Water Development Board. Jamuna-Meghna River Erosion Mitigation Project Part B. In Special Report 17, Geobag Revetments; Government of the People's Republic of Bangladesh, Asian Development Bank and Bangladesh Water Development Board: Dhaka, Bangladesh, 2006.

4. Bezuijen, A.; De Groot, M.B.; Breteler, M.K.; Berendsen, E. Placing accuracy and stability of geocontainers. Proc. EuroGeo 2004, 3.

5. Dassanayake, D.T.; Oumeraci, H. Engineering properties of geotextile sand containers and their effect on hydraulic stability and damage development of low-crested/submerged structures. Int. J. Ocean Clim. Syst. 2012, 3, 135-150. [CrossRef]

6. Dassanayake, D.T.; Oumeraci, H. Important engineering properties of geotextile sand containers and their effect on the hydraulic stability of GSC-structures. Terra Aqua J. 2012, 127, 3-11.

7. Recio, J.; Oumeraci, H. Process based stability formulae for coastal structures made of geotextile sand containers. Coast. Eng. 2009, 56, 632-658. [CrossRef]

8. Recio, J.; Oumeraci, H. Processes affecting the hydraulic stability of coastal revetments made of geotextile sand containers. Coast. Eng. 2009, 56, 260-284. [CrossRef]

9. Saathoff, F.; Oumeraci, H.; Restall, S. Australian and German experiences on the use of geotextile containers. Geotext. Geomembr. 2007, 25, 251-263. [CrossRef]

10. Oumeraci, H.; Hinz, M.; Bleck, M.; Kortenhaus, A. Sand-filled geotextile containers for shore protection. In Proceedings of the Coastal and Port Engineering in Developing Countries VI, Colombo, Sri Lanka, 15-19 September 2003.

11. Jackson, A.; Corbett, B.; Restall, S. Failure modes \& stability modelling for design of sand filled geosynthetic structures. In Proceedings of the 30th International Conference on Coastal Engineering, San Diego, CA, USA, 3-8 September 2006; pp. 1-20.

12. Mori, E.; Amini, P.L.; Eliso, C.D. Field experiment on a groin system built with sand bags. In Proceedings of the International Conference on Coastal Engineering, Hamburg, Germany, 31 August-5 September 2008; p. 219.

13. Northwest Hydraulics Consultants (NHC). Jamuna-Meghna River Erosion Mitigation Project Part B. In Special Report 11, Physical Model Study (Vancouver, Canada), Final Report; Government of the People's Republic of Bangladesh, Asian Development Bank and Bangladesh Water Development Board: Dhaka, Bangladesh, 2006.

14. Akter, A.; Wright, G.; Crapper, M.; Pender, G. Failure Mechanism in Geobag Structure. In Proceedings of the 4th IASME/WSEAS International Conference on Water Resources, Hydraulics and Hydrology (WHH'09), Cambridge, UK, $24-26$ February 2009.

15. Oberhagemann, K.; Hossain, M. Geotextile bag revetments for large rivers in Bangladesh. Geotext. Geomembr. 2011, 29, 402-414. [CrossRef]

16. Akter, A. Modelling of Geobags for River Bank Protection. Ph.D. Thesis, Heriot-Watt University, Edinburgh, UK, 2011.

17. Akter, A.; Pender, G.; Wright, G.; Crapper, M. Performance of a geobag revetment. I: Quasi-physical modeling. J. Hydraul. Eng. 2013, 139, 865-876. [CrossRef]

18. Oberhagemann, K.; Stevens, M.A.; Haque, S.M.S.; Faisal, M.A. Geobags for Riverbank Protection. In Proceedings of the ICSE-3rd International Conference on Scour and Erosion, Amsterdam, The Netherlands, 1-3 November 2006.

19. British Standards Institution (BSI). Hydrometry. In Measurement of Liquid Flow in Open Channels Using Current-Meters or Floats; BSI: London, UK, 2007.

20. Akter, A.; Pender, G.; Wright, G.; Crapper, M. Predicting the Hydrodynamic Forces on Geobag Revetments. J. Flood Risk Manag. 2011, 4, 328-338. [CrossRef]

21. Dassanayake, D.T. Experimental and Numerical Modelling of the Hydraulic Stability of Geotextile Sand Containers for Coastal Protection. Ph.D. Thesis, Technical University of Braunschweig, Braunschweig, Germany, 2013. 